A. MARCINIUK-KLUSKA ${ }^{1)}$, I. CHRZĄŜ́CIK ${ }^{2)}$

M. SZYMALSKA ${ }^{3)}$, M. KLUSKA ${ }^{2)}$

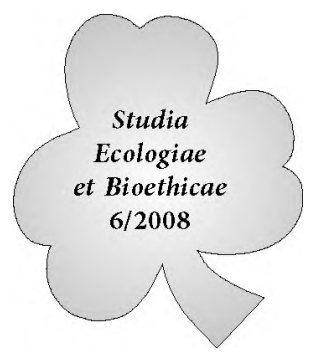

\title{
Rozwój innowacji a polityka ekologiczna Polski i Unii Europejskiej
}

\section{Wprowadzenie}

Według Głównego Urzędu Statystycznego przez innowacyjność rozumie się zdolność przedsiębiorstw do tworzenia i wdrażania innowacji oraz faktyczną umiejętność wprowadzania nowych i zmodernizowanych wyrobów, nowych lub zmienionych procesów technologicznych lub organizacyjno - technicznych. Natomiast innowacyjność gospodarki to zdolność podmiotów gospodarczych do ustawicznego poszukiwania i wykorzystania w praktyce nowych wyników badań naukowych, prac badawczo - rozwojowych, nowych koncepcji, pomysłów i wynalazków [1,2]. Można też ogólnie stwierdzić, że innowacyjność gospodarki jest wynikiem innowacyjności poszczególnych podmiotów gospodarczych, jakimi są przedsiębiorstwa.

Ogólnie innowacje można podzielić na dwa rodzaje $[3,4]$ :

a) Innowację produktową - dotyczącą wyrobów i procesów: są to wszelkiego rodzaju zmiany polegające na udoskonaleniu wyrobu już wytwarzanego przez przedsiębiorstwo, bądź na rozszerzeniu struktury asortymentowej o nowy produkt (zarówno towary, jak i usługi). Produkt nowy pod względem technologicznym jest to produkt, którego cechy technologiczne lub ich przeznaczenie różnią się znacząco od uprzednio wytwarzanych. Innowacje tego typu mogą wiązać się z całkowicie nowymi technologiami, opierać się na połączeniu istniejących technologii w nowych zastosowaniach lub też na wykorzystaniu nowej wiedzy. Uważa się, że innowacja produktowa została wdrożona, jeśli została wprowadzona na rynek.

b) Innowacje procesowe (technologiczne). Zaliczane są wszelkiego rodzaju zmiany w stosowanych przez organizację metodach wytwarzania, a także $\mathrm{w}$ sposobach docierania $\mathrm{z}$ produktem do odbiorców. Innowacje te zwykle

\footnotetext{
Wydział Zarządzania, Akademia Podlaska, Siedlce

Instytut Chemii, Akademia Podlaska, Siedlce

Wydział Nauk Przyrodniczych, Wszechnica Mazurska w Olecku
} 
polegają na dokonywaniu zmian w urządzeniach lub w organizacji produkcji, mogą też stanowić połączenie tych dwóch rodzajów zmian lub być wynikiem wykorzystania nowej wiedzy. Mogą mieć one na celu produkcje lub dostarczenie nowych lub udoskonalonych produktów, które nie mogłyby być wytworzone czy też dostarczone przy pomocy metod konwencjonalnych. Celem tych metod może być także zwiększenie efektywności produkcji lub dostarczenie istniejących produktów.

Nieco odmienny podział innowacji podaje Komisja Europejska w programie EQUAL. Podana przez UE definicja innowacji oparta jest na typologii wynikłej z ocen programów Employment i Adapt, która rozróżnia trzy typy innowacji [5-7]:

1) Innowacje zorientowane na proces, które dotyczą rozwoju nowych metod, instrumentów i podejść, jak również poprawy istniejących metod,

2) Innowacje zorientowane na cel, które koncentrują się wokół formułowania nowych celów oraz podejść w kierunku zidentyfikowania nowych i obiecujących kwalifikacji oraz tworzenia nowych obszarów zatrudnienia na rynku pracy

3) Innowacje zorientowane na kontekst, które odnoszą się do struktur politycznych i instytucjonalnych. Dotyczą one rozwoju systemu na rynku pracy.

Innowacje, jak każdy proces, przebiegają w określonych etapach. Różne źródła a także uczeni publikują różne definicje tych etapów. \aka różnorodność pojęć i definicji prawdopodobnie wynika $z$ interdyscyplinarności procesu innowacyjnego. Innowacje powstają, są wdrażane, w złożonym otoczeniu z wykorzystaniem wielu elementów, przy udziale czynnika ludzkiego. Cały proces innowacyjny traktowany jest jako zjawisko powstawania, dojrzewania i upowszechniania idei technicznych, ich praktycznego zastosowania, któremu towarzyszą określone skutki ekonomiczno-społeczne. Na tak rozumiany proces innowacyjny składają się wszystkie fazy zmian technologicznych, a więc inwencja (pomysł), innowacja (wynalazek) i dyfuzja, czyli upowszechnienie.

Dokonując analizy procesów innowacyjnych łatwo zauważyć występowanie następujących prawidłowości:

- cykl innowacyjny jest indywidualnie zróżnicowany i zależy od wielu czynników, wśród których istotne znaczenie ma poziom rozwoju gospodarki oraz sektorowe umiejscowienie innowacji jako dziedziny techniki, w której zachodzi proces innowacyjny,

- $\quad$ w miarę rozwoju cywilizacji obserwuje się skracanie cykli innowacyjnych poszczególnych produktów czy technologii, a także powstawanie tzw. kolejnych generacji produktów,

- $\quad$ współczesne innowacje częściej niż w przeszłości są efektem pracy zespołowej,

- niekiedy jest niemożliwe wyróżnienie indywidualnego autora określonego wynalazku. 
Reasumując powyższe prawidłowości można stwierdzić, że proces innowacyjny to zespół powiązanych ze sobą działań, prowadzących do urzeczywistniania idei naukowych, to znaczy przekształcania ich w środki materialne, nadające się do praktycznego wykorzystania. 『aki proces zawsze składa się z kilku etapów [4]:

Etap I. Badań podstawowych, które służą rozwojowi określonych dyscyplin naukowych poprzez dokonywanie odkryć i tworzenie teorii.

Etap II. Przekształcania idei naukowych w inwencje, czyli pomysł praktycznego wykorzystania idei naukowej w rozwiązaniu praktyczno-użytecznym. Jest to etap tzw. badań stosowanych, obejmujących: studia nad rozwojem technicznym, badania laboratoryjne oraz opracowanie założeń konstrukcyjnych nowego rozwiązania.

Etap III. Prac rozwojowych mających na celu przekształcenie inwencji w innowację, czyli doprowadzenie do budowy prototypu, co oznacza pierwszy funkcjonujący egzemplarz nowego urządzenia.

Etap IV. Prac wdrożeniowych, które mają za zadanie umożliwienie zastosowania rozwiązania na skalę przemysłową, poprzez opracowanie odpowiedniej technologu wytwarzania oraz niezbędnej dokumentacji produkcyjnej i sprawdzenie ich poprawności dzięki wykonaniu serii próbnej nowego wyrobu. Całość etapów od II do IV określa się pojęciem przygotowania techniczno-organizacyjnego produkcji, które obejmuje etap perspektywicznego przygotowania produkcji, tj. ustalania założeń rozwojowych na podstawie badania stanu i tendencji rozwoju techniki oraz przygotowanie konstrukcyjne, technologiczne i organizacyjne procesu wytwarzania.

Wprowadzając innowacje należy pamiętać, iż na wszystkich etapach powinien być prowadzony rachunek ekonomicznej efektywności projektu.

\section{Polityka ekologiczna UE w kierunku ekoinnowacji}

Polityka ekologiczna jest obecnie jednym z najszybciej rozwijających się obszarów współpracy krajów należących do Unii Europejskiej. Wraz z 『raktatem z Maastricht (1991r.) Wspólnoty Europejskie włączyły ją do spisu swych stałych zadań i określiły cele działań w zakresie ochrony środowiska naturalnego, tzw. proekologii. Polityka ekologiczna Wspólnot Europejskich początkowo była skierowana przeciw skutkom zanieczyszczenia środowiska. Z czasem zaczęła dotyczyć działań zapobiegawczych. W traktatach założycielskich Wspólnot Europejskich z 1957 roku nie poruszono kwestii związanych z ekologią. Kraje członkowskie musiały radzić sobie samodzielnie z rosnącym zanieczyszczeniem środowiska. Wkrótce problem nabrał znaczenia międzynarodowego. Państwa nie zapobiegające zanieczyszczeniom potrafiły zniweczyć wysiłki sąsiednich krajów postępujących w tych sprawach bardziej rygorystycznie. Polityka ochrony środowiska i normy produkcyjne państw członkowskich coraz bardziej utrudniały 
handel. 囚ym samym stanęły na drodze swobodnego przepływu towarów, stanowiącemu cel Wspólnoty Europejskiej [8-10].

Na początku lat 70 szefowie państw i rządów WE wezwali Komisje Europejską do opracowania programu na rzecz ochrony środowiska. Za podstawę prawną uznano \raktat EWG, mówiący o „harmonijnym rozwoju życia gospodarczego" oraz o „stałej gospodarce zrównoważonego rozwoju” w państwach członkowskich Wspólnoty. Dla potrzeb ochrony środowiska wykorzystany został również artykuł 100 \raktatu EWG, przewidujący harmonizację tych przepisów prawa, które bezpośrednio wpływają na funkcjonowanie wspólnego rynku. Polityka ochrony środowiska została uznana za niezbędną i zyskała podstawy prawne. Skutkiem tych decyzji było powstanie wspólnotowego prawa ochrony środowiska, które obecnie skierowane jest na ekoinnowacje i działania proekologiczne [11].

Zarówno ekoinnowacje, jak i działania proekologiczne są priorytetami dla Unii Europejskiej, która jest głównym koordynatorem polityki ochrony środowiska w Europie. UE stara się podejmować właściwe kroki we wszystkich dziedzinach istotnych dla środowiska. \akie działanie napotyka na coraz silniejszy opór w tych dziedzinach gospodarki, które są objęte surowszymi sankcjami za zanieczyszczanie. Przykładem mogą być europejscy przemysłowcy, którzy sprzeciwili się wprowadzeniu podatku energetycznego. Uważali oni, że stracą atrakcyjność cenową w stosunku do konkurentów z USA i Japonii. Skutkiem był fakt, iż Komisja Europejska wycofała się z kilku planowanych aktów prawnych, m.in. $\mathrm{z}$ wprowadzenia podatku od emisji dwutlenku węgla $[12,13]$.

Obecnie w UE obowiązuje jedenaście zasad ekologicznych [8]:

1. Lepiej zapobiegać, niż leczyć,

2. Należy uwzględniać skutki oddziaływania na środowisko w możliwie najwcześniejszym stadium podejmowania decyzji,

3. \rzeba unikać eksploatowania przyrody powodującego znaczne naruszenie równowagi ekologicznej,

4. Należy podnieść poziom wiedzy naukowej, by umożliwić podejmowanie właściwych działań w zakresie innowacji,

5. Koszty zapobiegania i usuwania szkód ekologicznych powinien ponosić sprawca zanieczyszczenia,

6. Działania w jednym państwie członkowskim nie powinny powodować pogorszenia stanu środowiska w innym,

7. Polityka ekologiczna państw członkowskich w zakresie ochrony środowiska musi uwzględniać interesy państw rozwijających się,

8. Państwa Unii Europejskiej powinny wspierać ochronę środowiska w skali międzynarodowej i globalnej,

9. Ochrona środowiska jest obowiązkiem każdego, zatem konieczna jest edukacja w tym zakresie. 
10. Środki ochrony środowiska powinny być stosowane odpowiednio do rodzaju zanieczyszczenia, potrzebnego działania oraz obszaru geograficznego, który mają chronić. Zasada ta znana jest jako zasada subsydiarności,

11. Krajowe programy dotyczące środowiska powinny być koordynowane na podstawie wspólnych długoterminowych programów, a krajowa polityka ekologiczna - harmonizowana w ramach Wspólnoty Europejskiej.

\section{Wprowadzane technologie a wymagania UE}

Kraje Unii Europejskiej mają na celu nie tylko niedopuszczanie do zanieczyszczania przyrody lub likwidacje powstałych szkód, lecz przede wszystkim zachowanie przezorności ekologicznej. Jest to możliwe dzięki stosowaniu ekoinnowacji, czyli najlepszej dostępnej technologii (Best Available 『echnology - BA囚), tzn. takich metod działania, takich rozwiązań organizacyjnych, a przede wszystkim takich urządzeń technicznych, które najlepiej redukują i unieszkodliwiają zanieczyszczenia. BA囚 został wprowadzony przez EWG w 1984 roku dyrektywą 84/360 w sprawie zwalczania zanieczyszczeń powietrza atmosferycznego, pochodzących z zakładów przemysłowych. W 1996 roku została przyjęta dyrektywa 96/61, która w nowych zakładach obowiązuje od 1999 roku, a w zakładach starszych już istniejących obowiązuje dopiero od roku 2007. Zgodnie z tą dyrektywą każdy producent stanowiący potencjalne zagrożenie dla środowiska i zdrowia ludzi musi uzyskać zintegrowane pozwolenie ekologiczne. Pozwolenie to określa emisje zanieczyszczeń na poziomie, który będzie bezpieczny dla środowiska naturalnego jako całości oraz zapobiegnie przemieszczaniu się zanieczyszczeń z jednego elementu środowiska do następnego. W myśl dyrektywy 96/61 zintegrowane zezwolenie jest wydawane przy udziale społeczeństwa, dzięki czemu społeczności lokalne mają wpływ na podejmowanie decyzji ich dotyczących [14-17].

W ramach działan proekologicznych i ekoinnowacyjnych do 2010 roku, Unia Europejska zamierza zrealizować szereg zadań, m.in. [17]:

- uregulować gospodarkę ściekową we wszystkich miejscowościach powyżej 100000 mieszkańców, zgodnie z wymaganiami Dyrektywy 91/271/EEC, realizacja programów gospodarki ściekowej w mniejszych miastach,

- osiągnąć taką jakość wód powierzchniowych przeznaczonych do spożycia, aby spełnione były wymagania UE,

- realizować inwestycje na rzecz poprawy jakości powietrza w miastach, w których dochodzi do przekraczania dopuszczalnych poziomów zanieczyszczenia powietrza,

- realizować inwestycje proekologiczne w zakładach produkcyjnych odprowadzających niebezpieczne substancje do wód,

- stworzyć ogólnokrajowe oraz regionalne i lokalne systemy gospodarki odpadami, 
- wdrażać istniejące programy gospodarki odpadami w mniejszych miejscowościach,

- zakończyć inwestycje ochrony środowiska w rafineriach i zakładach zajmujących się magazynowaniem i transportem produktów ropopochodnych.

Wiele z powyższych założeń została już zrealizowana, jednak musimy pamiętać, że ochrona środowiska nie jest działaniem jednorazowym i nie można oczekiwać efektów z dnia na dzień. Działania ochronne musza być długofalowe, dlatego UE po 2010 roku również zaplanowała pewne działania. Do najważniejszych z nich można zaliczyć:

- pełne uregulowanie gospodarki ściekowej w miastach powyżej 2000 mieszkańców, zgodnie z wymaganiami Dyrektywy 91/271/EEC,

- ochrona wszystkich zbiorników wód stojących przed zanieczyszczeniami ściekami (przede wszystkim pestycydami i nawozami sztucznymi), w takim zakresie, aby było to uzasadnione ekologicznie i ekonomicznie, łącznie z rozwiązaniem problemu zanieczyszczeń pochodzenia rolniczego,

- zorganizowanie takiego systemu wywozu odpadów komunalnych, aby objęte nim było 95\% mieszkańców, zakończenie realizacji programów gospodarki odpadami w miastach i w mniejszych miejscowościach,

- zakończenie realizacji programu gospodarki odpadami niebezpiecznymi.

Powyższe zadania dotyczą obecnie także Polski. Wcześniej, a mianowicie do początku lat 90, nie prowadzono żadnych działań w Polsce mających na celu ochronę środowiska oraz wprowadzanie innowacji proekologicznych. Dopiero od końca lat 80-tych można zaobserwować w Polsce znaczny postęp w zakresie ochrony środowiska. Zmniejszona została emisja zanieczyszczeń do atmosfery i wód, zwiększony został obszar Polski objęty ochroną prawną, a także przystąpiono do wielu międzynarodowych konwencji ekologicznych. Od roku 1991 zwiększono znacznie nakłady na inwestycje ochrony środowiska w Polsce. W roku 1991 nakłady te wynosily 0,8 mld USD, a w 1997 już 2,3 mld USD co stanowiło 1,6\% PKB [18-21].

Dzięki inwestowaniu w środowisko, wprowadzaniu ekoinnowacji, jak i wdrażaniu mechanizmów prawnych i ekonomicznych do polityki ekologicznej nastąpiła istotna poprawa stanu środowiska. Na początku lat 90-tych poprawa stanu środowiska była efektem przestawiania się gospodarki polskiej z modelu jaki obowiązywał w państwie socjalistycznym, na model jaki obowiązuje w państwie demokratycznym z gospodarką wolnorynkową. Obecnie jednak jakość środowiska poprawia się dzięki zmianom w polskim prawie i stworzeniu dobrego systemu finansowania ochrony środowiska.

Jednak nie ulega wątpliwości, że ekoinnowacyjność w Polsce jest jeszcze daleko w tyle za UE. Nadrabianie zaległości rozwojowych w ogólnym obszarze innowacyjności w stosunku do średniej UE zajmie nam według prognoz około 18 lat $[22,23]$. Średnia wartość innowacyjności dla UE wynosi 0,45 , natomiast dla Polski zaledwie 0,24 (Rys. 1). 


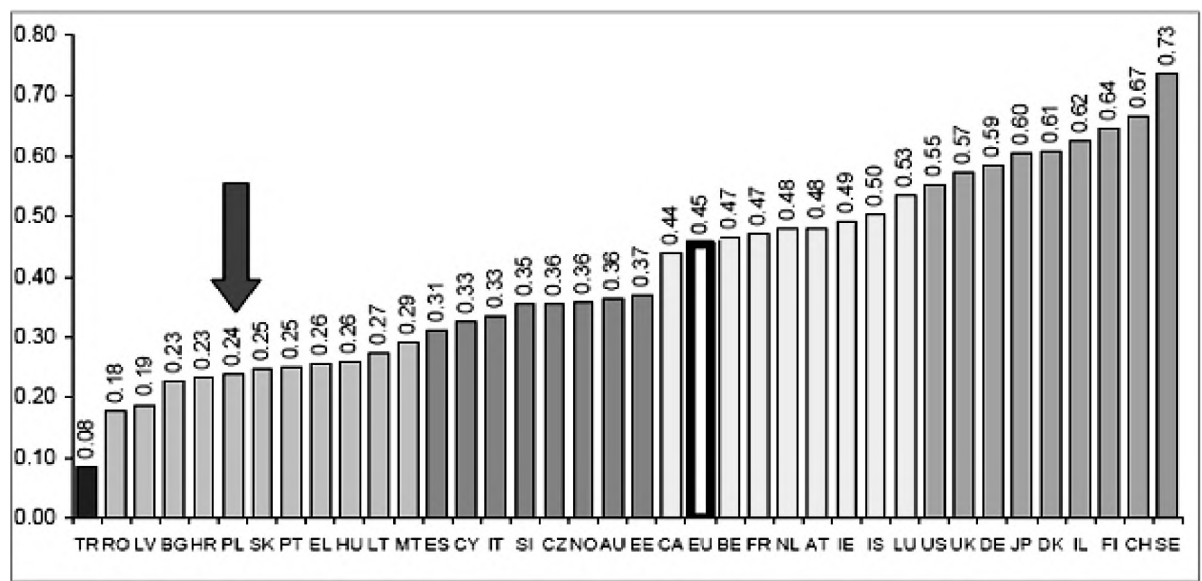

Rys. 1. Pozycja Polski (zaznaczona strzałka) w rankingu innowacyjności - European Innovation Scoreboard 2007 [22].

Poziom innowacyjności gospodarki polskiej jest bardzo niski. Syntetycznym miernikiem tego są nakłady na $\mathrm{B}+\mathrm{R}$, które w Polsce wynoszą 0,57\% PKB, podczas gdy w Unii Europejskiej prawie 1,9\% (Rys. 2a, b). W związku z tym w tzw. drugim okresie programowania postanowiono zgodnie z zaleceniami Odnowionej Strategii Lizbońskiej znaczną część środków pomocowych UE przeznaczyć na innowacje przede wszystkim w ramach Programu Operacyjnego Innowacyjna Gospodarka oraz 16 Regionalnych Programach Operacyjnych [22]. Nie ulega wątpliwości, że konieczny jest wzrost nakładów na $\mathrm{B}+\mathrm{R}$. Optymalny poziom finansowania prac $B+R$ powinien stanowić $2 / 3$ środków od podmiotów gospodarczych.

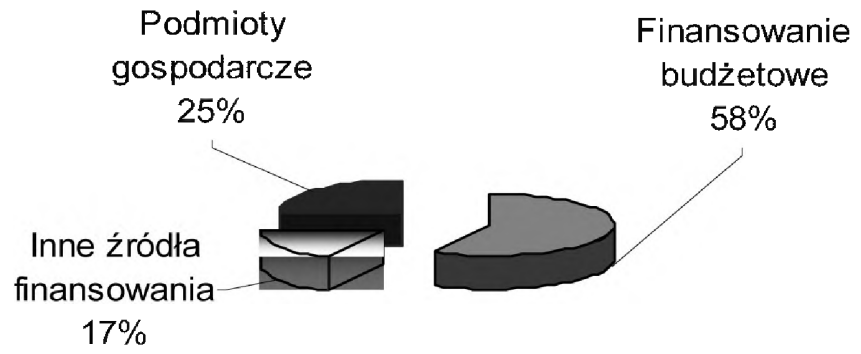

a) 


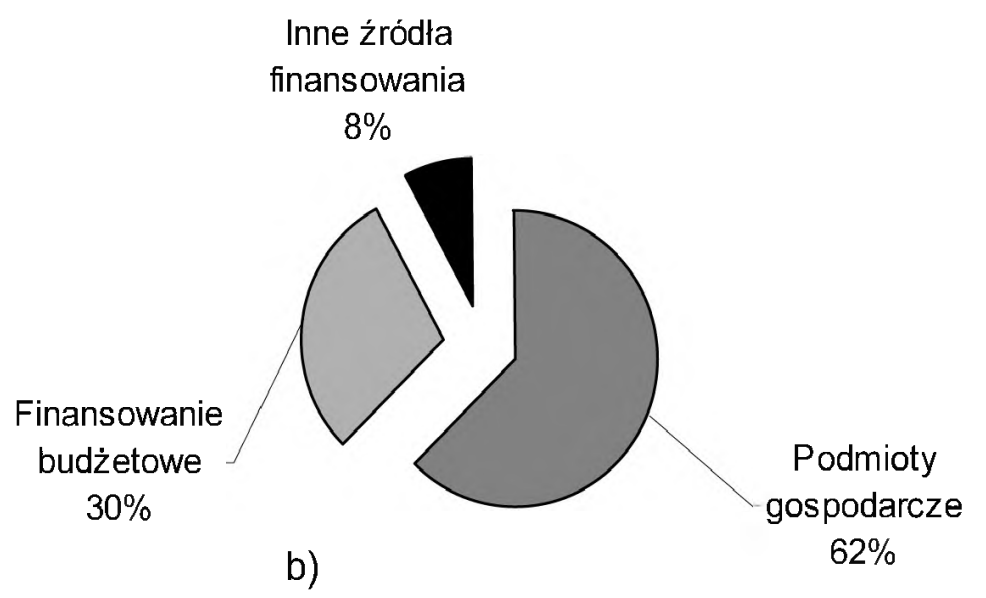

Rysunek 2. Odsetek przedsiębiorstw prowadzacych działalność innowacyjng w krajach: a) UE $i$ b) OECD [24].

\section{Podsumowanie}

Innowacje czy restrukturyzację można postrzegać jako zagrożenie lub jako wykorzystanie dogodnej okazji. Zarówno w Polsce, jak i w UE istnieje potrzeba innowacji, szczególnie ekoinnowacji. Zakres potrzeb innowacyjnych jest szerszy i znacznie wykracza poza ekologię. Innowacje konieczne są również w przemyśle, aby np. europejskie produkty nie musiały obawiać się importu z Chin i były pewne swojej przewagi nad konkurencją. Nie tylko muszą to być innowacje technologiczne. Należy raczej wypracować taki sposób myślenia, który nie pozwoli nam zachować obecnego stanu rzeczy, lecz zachęci do ulepszenia produktu lub metod produkcji, projektowania czy sprzedaży. Upowszechnienie takiego myślenia stanowi duże wyzwanie. Coraz więcej osób angażuje się w strategie dotyczące innowacji. Wszystkie Fundusze Strukturalne, fundusze regionalne uczyniły z innowacji jedno z głównych kryteriów prowadzonych inwestycji.

Największym źródłem innowacji dla prawie 10 milionów europejskich firm zatrudniających co najmniej dwie osoby, pomijając $1 \%$ naprawdę dużych przedsiębiorstw, są nowi pracownicy. Ich wiedza i umiejętności znacznie zwiększają zdolność do podejmowania nowych inicjatyw. Dlatego tak ważne jest wspieranie działań umożliwiających wymianę informacji i doświadczeń na szczeblu europejskim. 


\section{LI冈ERA囚URA}

1. Założenia polityki proinnowacyjnej państwa, KBN, Warszawa listopad 1994.

2. PoZNÁ́sKi K., Innowacje w gospodarce kapitalistycznej, PWN, Warszawa 1979.

3. JAsIŃski A., Innowacje i polityka innowacyjna, Wydawnictwo Uniwersytetu w Białymstoku, Białystok 1997.

4. Byrski B., Procesy innowacyjne w przemyśle, Akademia Ekonomiczna w Krakowie, Kraków 1996.

5. Maślanka B., System innowacji Polski w kontekście Strategii Lizbońskiej, [w:] E. OkońHoRodyńsKa, S. PANGSY-Kania (red.), Innowacyjność w budowaniu gospodarki wiedzy w Polsce, Instytut Wiedzy i Innowacji, Warszawa 2007.

6. Some thoughts on Definitions of Innovation, The Innovation Journal, November 20.1999.

7. GOAL/QPC囚RIZ, An Approach to systematic innovation, 1997.

8. http://ec.europa.eu/growthandjobs/annual-report-1206_en.htm

9. http://ec.europa.eu/enterprise/index_pl.htm

10. Van BeuzeKom B., ARundel A., OECD Biotechnology Statistics - 2006, OECD 2006,

11.Ernst \& Young, Wanted: A Renewable Europe, 2007, www.ey.com.pl.

12.Europejski portal dla MSP, http://ec.europa.eu/enterprise/sme/innovation_pl.htm.

13. National Innovation Policy of The Czech Republic For 2005-2010, Praga 2005.

14. Drucker P., Innowacja i przedsiębiorczość. Praktyka i zasady, PWE, Warszawa 1992.

15. WISZNIEWSKI W., Innowacyjność polskich przedsiębiorstw przemystowych. Procesy dostosowawcze do polityki innowacyjnej Unii Europejskiej", ORGMASZ, Warszawa 1999.

16. National Science Board, Science and Engineering Indicators 2006, National Science Foundation, 2006, http://www.nsf.gov/statistics/seind06/pdfstart.htm.

17. Vanhanen V., Financing innovation and grown, Directorate-General for Enterprise and Industry Financing SMEs, entrepreneurs and innovators, European Commission, 2007.

18. Ustawa o niektórych formach wspierania działalności innowacyjnej z dnia 29 lipca 2005 roku (Dz. U. z 2005 r., nr 179, poz. 1484) zmieniona w 2006 roku Ustawą z dnia 12 maja 2006 roku o zmianie ustawy o niektórych formach wspierania działalności innowacyjnej oraz niektórych innych ustaw (Dz. U. 2006 r., nr 107, poz. 723).

19. Ustawa o zasadach finansowania nauki z dnia 10 września 2004 roku.

20.Założenia polityki naukowej, naukowo-technicznej i innowacyjnej państwa do 2020 roku, Ministerstwo Nauki i Informatyzacji, Warszawa 2008.

21. Finansowanie rozwoju mikrofirm - czy przedsiębiorcy mogą liczyć na banki? Pentor 2005, www.pentor.pl.

22. Proponowane kierunki rozwoju nauki i technologii w Polsce do 2020 roku, Ministerstwo Nauki i Informatyzacji, Warszawa 2004.

23. Science and Dechnology, [w:] Statistics in Focus, Eurostat, 6/2004.

24. Główny Urząd Statystyczny, Warszawa 2008. 


\section{The development of innovation and ecological strategy of Poland and the European Union}

\section{SUMMARY}

The paper presents the ecological strategy of the European Union and Poland as well as the aspects of the needs to implement innovations. The fast growth of the economy is influencing natural habitat more and more negatively. And at this stage new and more efficient technologies should be implemented and particularly eco-innovations. As the European Union directs more and more funds into this area, it becomes easier to receive financial aid. But the needs in this area are still enormous. They are particularly visible in those places where the danger zones for the natural habitat exist.

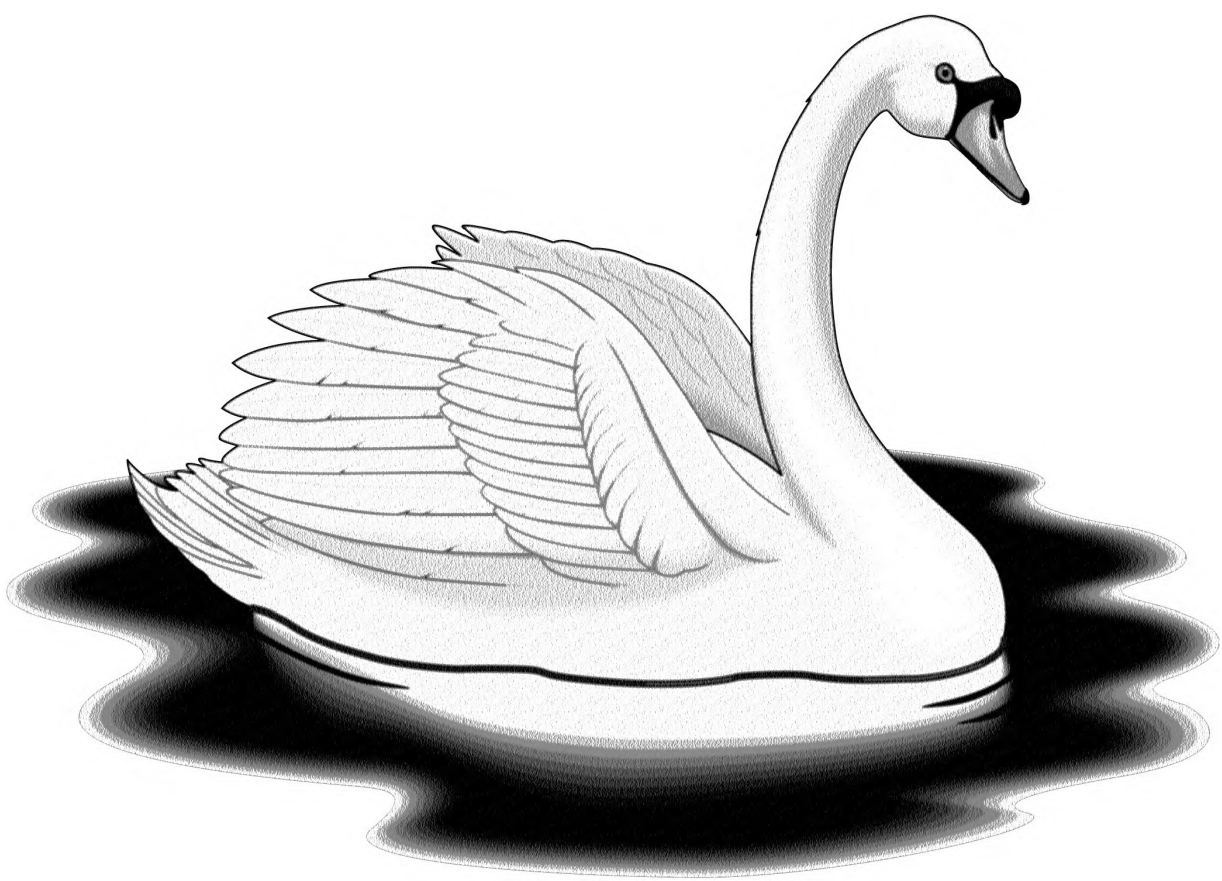

